\title{
Kynanthropy: canine madness in Byzantine late antiquity
}

\section{Nadine Metzger}

Friedrich-Alexander-Universität Erlangen-Nürnberg (FAU)

\begin{abstract}
Those afflicted bark like dogs, scramble on all fours and loiter around graveyards - canine madness, referred to as kynanthropy, was an illness concept in its own right in the medicine of late antiquity. At roughly the same time as the medical description produced by Aëtius of Amida, the Syrian chronicler John of Ephesus, also from Amida, reported an epidemic of dog-like madness sweeping his home town in AD 560. The symptoms are identical and both authors are from Amida - what is the connection between the two depictions? In addition to the history of the medical concept, the example of the canine madness of Amida and its cultural embedding allows us to contextualize and interpret the significance of dog-like behaviour for the people of the sixth century AD.
\end{abstract}

\section{Keywords}

Aëtius of Amida, demonic possession, John of Ephesus, late antiquity, lycanthropy, melancholy

\section{Introduction}

The medical compendium by Aëtius of Amida from the sixth century AD dedicates an astonishing amount of space to the illness kynanthropy. This melancholic illness receives an entire chapter in combination with lycanthropy (Aëtius VI 11, Olivieri, 1950: 151-2). Dog and wolf are thus the only two animals whose imitation the medicine of late antiquity categorizes as illness concepts in their own right. Both of these forms of madness must have had particular relevance for authors during this period.

I have written extensively about wolfish madness in other works (Metzger, 2011, 2013); in comparison, there is much less mention made of dog-like madness in the ancient and late ancient sources. Aëtius is the only medical author whose work on kynanthropy has been preserved. Further mentions of the term 'kynanthropy' from antiquity and late antiquity can only be found in astrological writings. However, the Syrian ecclesiastical historian John of Ephesus does report an epidemic of dog-like madness which swept the Mesopotamian metropolis Amida in AD 560, the home town of both himself and Aëtius (John of Ephesus in the Zuqnin Chronicle, Witakowski, 1996: 
104-7). This detailed description of canine madness, produced at roughly the same time as Aëtius's medical treatise on kynanthropy, allows us to contextualize the latter.

Although they are written in different languages and belong to very different text genres, the medical description of kynanthropy and the ecclesiastical history report of the canine madness in Amida list the same symptoms for the affliction. How can this correlation be explained? Is there a direct connection - involving the shared home town of Amida - between the canine madness reported and the medical concept? Or does canine madness possess a significance beyond Amida, perhaps for the entire Byzantine world in a period longer than just the sixth century?

The sixth century in Byzantium was decisively characterized by the rule of Justinian (AD 527565), during which time the canine madness of Amida occurred. Justinian not only built the Hagia Sophia and won back lost territories in the west for the hitherto shrinking Empire, but also ruled during the outbreak of the pandemic 'Justinian Plague'. The majority of the population was of Christian faith, with community life and imperial rule being imbued with Christian values. In scholarly literature, however, including the field of medicine, the ideals of classical antiquity still heavily influenced form and content: an attempt was made to imitate the ancient greats in terms of language, style and content (mimesis). Extensive medical compendia categorized and systematized the knowledge handed down from ancient times. Behind the apparently stable tradition of ancient medical knowledge, however, the frame of reference had fundamentally changed in Christian late antiquity.

With its focus on Amida, this paper directs attention to the periphery of the Byzantine Empire: situated on the upper Tigris in Byzantine Mesopotamia, Amida was a border city caught within the political and cultural tension between Byzantium and the Sasanian Persian Empire (Dignas and Winter, 2007: 100-8; Harvey, 1990: 57-65; Segal, 1955). The majority of the indigenous population did not speak Greek, instead having their own Syriac culture. Moreover, they traditionally belonged to a Christian minority persecuted in Byzantium. This context had a decisive influence on the depiction of the dog-like madness of Amida by John of Ephesus, as will be shown later.

Kynanthropy connects Greek and Syriac authors, Constantinople and Mesopotamia, medical and ecclesiastical history, ancient tradition and the Christian interpretation of the world. Despite cultural and linguistic differences, the significance of the dog in the Byzantine Empire during the period under investigation (second century to sixth century AD) is so stable that Syriac and Greek depictions can be compared without reservation. Canine madness obviously seemed logical to both the afflicted persons in Amida in AD 560 and the learned physicians of the time. What exactly they meant by this and why canine madness was so significant for them will be examined in the following pages.

In order to do so, the canine madness of Amida and the medical concept of kynanthropy will first be illustrated in their respective contexts, including a discussion of a possible connection. All known references to the term 'kynanthropy' in the ancient and late ancient sources will then be discussed, providing indications as to the dissemination and significance of this rarely found illness concept. The importance of the dog in late antiquity will provide the background against which an understanding of the significance of canine madness can be comprehended. What exactly is expressed through canine madness in the world of late antiquity, in both the Syriac and the Greek contexts? Why specifically canine madness? And how should one interpret an entire epidemic of canine madness?

\section{Canine madness in Amida in AD 560}

First, writes the chronicler John of Ephesus, there was a rumour that the Persians were attacking the city! The residents of Amida, who were not unfamiliar with warfare and violent clashes, immediately began to panic and to undertake mindless attempts to save themselves and their property 
(John of Ephesus in the Zuqnin Chronicle, Witakowski, 1996: 104). Two generations previously, in 503, the city had fallen to the Persians following a three-month siege after a famine; there were said to have been 80,000 victims when the Persian army conquered Amida (Ps.-Joshua the Stylite, Trombley and Watt, 2011: 62; see also Greatrex, 1998: 83-94). These events from the childhood of their grandparents may well have played a role for the population as they fled from the alleged new attack of the Persian Emperor.

But desperate flight was only the first step, with the city soon descending into madness. People barked like dogs and imitated animals of all sorts. 'They gathered in groups, confused, disturbed, troubled and disordered, rushing here and there, in the night to the cemetery, going on madly, singing and behaving furiously, biting each other ...' (John of Ephesus in the Zuqnin Chronicle, Witakowski, 1996: 105). All morals and self-control had gone: they babbled and cursed, jumped around and threw themselves upon each other ('especially the young, boys and girls'), 'clung to the walls, hanged [i.e. hung, N.M.] themselves head downwards, fell, wallowed naked on the earth'. Some of them foamed at the mouth and behaved like mad dogs. They blasphemed and committed an outrage with their wild demeanour.

The monk John of Ephesus, himself a son of the city and a contemporary of the events, recorded the madness which afflicted Amida in 560. Although his Church History, written in Syriac, has been lost, later chronicles quoted from it extensively, for example the Zuqnin Chronicle (Witakowski, 1996: 104-7). This work, produced in the monastery of Zuqnin not far from Amida during the eighth century, quotes lengthy passages from John of Ephesus in its depiction of the (local) history of the first two-thirds of the sixth century (Witakowski, 1996: xv-xvi, xxvi-xxix), including the report on the madness in Amida in 560 in full.

John was no uninvolved observer. As a Syrian monk, who was raised and socialized in the monastery of Mar John Urtaya before the gates of the city of Amida, John was deeply affected by the fate of the city and its inhabitants. As an avowed Monophysite, John had been driven out of Mesopotamia at an early age, and when not on his extended missionary travels, he generally spent his time in Constantinople, where he hoped to be able to use the proximity to the Emperor's court to the benefit of his brethren in Mesopotamia (van Ginkel, 1995: 27-37). Following the Council of Chalkedon in $\mathrm{AD} 451$, which had officially determined the orthodox interpretation of the 'nature' in Jesus Christ, the Monophysites ('one nature'), who were mostly to be found in Egypt and Mesopotamia, were considered heretics and were persecuted to varying degrees depending on the Emperor and the archbishop responsible for their region. It can thus be reasonably safely assumed that John was not an eyewitness to the madness of 560, despite the claims of the Zuqnin Chronicle to the contrary (Witakowski, 1996: 107). But even from the distance of Constantinople, his entire work as an author, significantly written in Syriac, was in the service of the Monophysite cause: this cause was interwoven in his work with the history of his homeland, which he placed beneath the subject of religious persecution of the Monophysite monks and lay population (Harvey, 1990; van Ginkel, 1995).

Amida, now the Turkish city of Diyarbakır on the southern border with Iraq, was an important metropolitan city in northern Mesopotamia. Situated on the upper Tigris, it was extended and fortified during the clashes between the Byzantine and Persian Empires in late antiquity with thick defensive walls still visible today, which served to strengthen and protect the borders. The Syriacspeaking region of Mesopotamia, which was actually a geographically and culturally unified entity, was separated into a Byzantine part and a Persian part: a large proportion of the frequent clashes between the two Empires occurred on Mesopotamian soil (Dignas and Winter, 2007: 100-8; Harvey, 1990: 57-65; Segal, 1955).

In the sixth century $\mathrm{AD}$ alone, the region was almost permanently embroiled in warfare: stable peace agreements only lasted from 532 to 540, 562 to 572 and from 591 onwards (Dignas and Winter, 2007). For the Syriac-speaking civilian population, this meant that they became the victims 
of the power politics of their respective Byzantine or Persian rulers. They had to cope not only with large-scale warfare involving entire armies, sieges and conquests, which were admittedly relatively seldom, but also with smaller raids and skirmishes, changes of the occupying forces, the billeting of garrison troops, confiscation of food supplies and animals as well as labour and materials for the building of fortifications, and last but not least the permanent state of alert. The peasant population, which mostly consisted of serfs or dependent freemen living outside the high walls of the city, was particularly vulnerable to an attack, against which they were virtually defenceless. In the case of such an attack, they left their fields to seek refuge within the city, only to return afterwards to find their livelihoods destroyed. Raids were carried out not only by Persian soldiers, but also by White Huns (Hephthalites), who forced their way into the Persian Empire from the east, while attacks by lawless nomad tribes also plagued the border regions (Harvey, 1990: 57-65; Segal, 1955: 113-14, $118-19,129)$.

For Amida, the sixth century began with a significant man-made catastrophe, namely the siege and conquest of the city by the Persians from 502 to 503 (Chronicle of Ps.-Joshua the Stylite, Trombley and Watt, 2011; see also Greatrex, 1998: 83-94). The period of occupation which followed and the subsequent two-year siege and reconquest by the Byzantine army left the previously blossoming metropolis on the upper Tigris a shadow of its former self (Harvey, 1990: 59-61). Nearly 40 years later, the great 'Justinian' plague of 542 depopulated Amida along with other cities of the Byzantine Empire. The disease resulted in death for much of the population and brought about a collapse of civilization within society, as John of Ephesus chillingly portrays in his account. The great plague raged for three years in Mesopotamia and was followed by an eight-year famine, and further outbreaks of disease and earthquakes, before the canine madness struck Amida in 560 (John of Eph., Witakowski, 1996: 102-7).

Other parts of the Byzantine Empire were also hit by such catastrophes during the sixth century: war, religious persecution, the Justinian plague, repeated outbreaks of disease, famines, severe earthquakes and floods. In 536-37, an 'atmospheric disturbance' (Meier, 2003: 359-65) darkened the sun for several months, causing the weather and the seasons to become unpredictable, with failed harvests as a result. A series of threatening omens occurred: solar eclipses, comets, lightning strikes and sea monsters (a list can be found in Meier, 2003: 656-70). Meier (2003) has described the sixth century as an age of fear.

John of Ephesus's chronicle is heavily influenced by the great catastrophes of the sixth century. Against the background of so many disastrous omens, he mentions the various signs of approaching doom 'everywhere in the sky and on the earth' only in summary (Witakowski, 1996: 104). Since his Church History focuses on the fate of the Monophysite church in Mesopotamia, especially the religious persecution by particularly committed opposing bishops and patriarchs, he interprets the catastrophes of the sixth century in precisely this context, as God's punishment for the fact that so many people had turned away from the 'true faith' in the face of pressure from the persecutions. He saw them as a trial sent to the people by God, with all being dependent on the mercy of God. Amida, in his view, bore the persecutions and disasters with patience and humility for more than 40 years: she 'endured a heroic struggle for the sake of the truth of her faith' (p. 103). John's history of Amida is imbued with symbolism, not only through the 40-year length of the suffering, but also through his comparison with the Biblical precedent in the book of the prophet Jeremiah (p. 102). John sees his church as a direct descendant of Biblical events, and the historical occurrences as part of a divine salvation plan. In the course of the catastrophes and omens, the test of collective madness forms a dramatic climax: this 'terrible, abominable and hideous affliction' (p. 104) represents the final act in a 40-year period of terror.

In contrast to the other catastrophes, the madness of Amida in 560 posed a mental rather than a physical threat to the city. It neither decimated a significant proportion of the population nor did it 
threaten the lives of the people as directly as a famine would, but rather it shook the basic foundations of the world order as perceived by John and his contemporaries. The mass onset of madness broke boundaries which had, until that point, been fundamental to the communal bonds of the mostly Christian society of Amida.

Dogs and the dog-like behaviour of those afflicted by the madness feature not only in the main body of John's depiction, but also very prominently at the beginning and the end of his account. While the victims imitate animals of all kinds, dogs are mentioned explicitly as the first of these; the list of symptoms starts: 'People began to bark like dogs'. Many of the behavioural patterns subsequently listed were considered by contemporaries to be typical of dogs: the formation among the sufferers of packs who roamed through the city, nocturnal loitering in graveyards, promiscuous behaviour, running on all fours, and of course behaving 'like mad dogs', 'foaming at the mouth' (Witakowski, 1996: 105).

\section{Dog madness in ancient medicine}

Another son of the city of Amida, a doctor named Aëtius, wrote a comprehensive medical compendium, also during the sixth century, which contains a description of the illness kynanthropy (i.e. dog madness) with symptoms similar to the madness of Amida. Aëtius's chapter is entitled 'On Lycanthropy or Kynanthropy' (Aëtius VI 11, Olivieri, 1950: 151-2), dealing with wolfish madness in addition to dog madness. The two are presented as comparable, with sufferers displaying signs of either wolf-like or dog-like behaviour. Is there a connection to the dog madness of Amida? Unfortunately it is not possible to pinpoint exactly when Aëtius lived or when his work was written. He was born in Amida and seems to have studied and practised first in Alexandria, before probably settling in Constantinople. He may have worked as a doctor at the Emperor's court, although it is possible that this position was incorrectly attributed to him at a later stage (Ieraci Bio, 2010; Martindale, 1980). All indications point to the fact that Aëtius (in contrast to John) belonged to Amida's small Greek upper class who could afford to send a son to be educated in Alexandria, the medical centre of the later ancient world. For the majority of Amidans, this would have been impossible simply due to the linguistic barrier. Aëtius's work can be vaguely dated to the first half or the middle of the sixth century (Ieraci Bio, 2010): he mentions a prominent personality from the fifth century (terminus post quem) and is himself quoted by Alexander of Tralles, whose work was written in the second half of the sixth century (terminus ante quem). It is thus possible that the madness of Amida in 560 played a role in his description of kynanthropy.

Aëtius's working methods, however, make such a link highly improbable. His medical compendium is a so-called collected edition: he aimed to present the entire medical knowledge of his time in compact form, thereby making extensive use of the techniques of quotation, excerption and summarizing. Only a few passages contain original work of the author himself or are based on his own practical experience. In contrast to other authors of late antiquity, however, Aëtius names his sources; the chapter which is of importance for us, namely that concerning kynanthropy, is taken from a didactic poem by Marcellus of Side, a physician from the second century AD (Nollé, 1993: 175). It is questionable, however, as to whether Aëtius actually had access to the poem itself. He most probably took the entire chapter directly from the monumental medical compendium by Oribasius from the fourth century AD. This work encompassed 70 volumes - Aëtius wrote 16 - but has unfortunately not been preserved, meaning that we can only reach this conclusion indirectly through comparisons with other excerpts from Oribasius. Oribasius himself wrote an abridged version of his compendium, the so-called 'Synopsis', dedicated to his son, in which he summarized basic medical knowledge in nine books (Metzger, 2011: 153). The relevant chapter contained in this work deals only with lycanthropy, i.e. wolfish madness, with no mention of dogs (Oribasius, 
Synopsis VIII 9, Raeder, 1926: 250). It can be assumed that he considered kynanthropy to be of lesser importance and therefore cut this illness out of the abridged version. Aëtius, however, seems to have kept the description of kynanthropy in his excerpt. This assumption is confirmed by a text comparison between Aëtius and Oribasius: Aëtius's chapter is altogether more rounded and more extensive, explaining the therapy more clearly. Oribasius's version in the 'Synopsis' leaves out all supposedly superfluous elements, leaving the text more dense and in some cases difficult to understand (Metzger, 2011: 151-3). It can be concluded that Aëtius's version is closer to the original text by Marcellus of Side than that of Oribasius. If Aëtius, as the author of a collected edition, simply copied his source closely, then his chapter on kynanthropy is almost certainly devoid of influence from the madness of Amida.

However, the depiction does prove that the symptoms occurring during the madness of Amida were known and recorded in medical circles, and it shows the way in which they were dealt with. Aëtius writes:

Those who are afflicted ... by so-called kynanthropy or lycanthropy roam out at night and mimic the ways

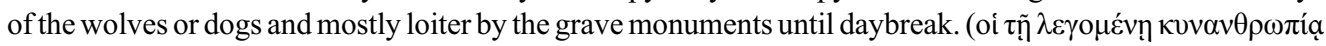

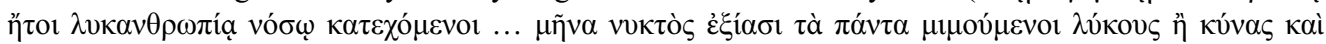

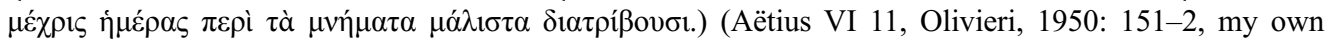
translation)

Furthermore, he mentions a range of physical symptoms such as pale skin, dry eyes and tongue, thirst and a lack of tear fluid and saliva. The permanent wounds on the shins of sufferers indicate that they moved about on all fours and received dog bites. Aëtius categorizes the illness as a form of melancholy, i.e. arising from an excess of black bile in the body. The dry quality of black bile is obviously seen as being responsible for the majority of the physical symptoms, which generally indicate a great dryness of the body. Aëtius's therapy suggestions thus aim to cleanse the body of black bile through venesection, special purgative medicines and clysters, and to moisten the body and encourage a healthy combination of the humours through medicines, baths and particularly through a special diet. It is the therapy lege artis of late antiquity and bears no surprises.

\section{Kynanthropy in astrological texts}

Aëtius of Amida is the only known medical author whose work mentions kynanthropy. Although it is to be assumed that his source, Marcellus of Side, described this form of canine madness as early as the second century AD, other authors of medical compendia (such as Oribasius) either considered kynanthropy to be less important than lycanthropy or had only Oribasius's abridged version of the compendium as a source. A treatise on melancholy, which also contains a chapter on kynanthropy and lycanthropy (Kühn, 1830: 719-20), was found within Galen's Corpus compiled by Kühn and wrongly attributed to Galen by the latter - and subsequently by others - but it is in fact an excerpt from Aëtius, as was clear from the end of the nineteenth century (Wellmann, 1893: 704). Aëtius thus remains the only surviving medical source.

The term 'kynanthropia' is only seldom found in the (edited) literature of Greek antiquity up to the early Byzantine period. All accessible sources, with the exception of Aëtius, originate from astrological compendia of late antiquity, particularly from the comprehensive collected edition by Rhetorius of Egypt from the sixth or seventh century AD which brings together excerpts from earlier authors. Rhetorius explains in two passages that a certain celestial configuration at the birth of a person marks them out as a kynanthrope: 
If sun and moon are in this Place [the Twelfth Place or House] while maleficent [planets] occupy a cardinal point and there is no positive influence in the right aspect, they cause the person born then to be a

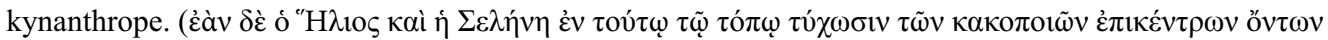

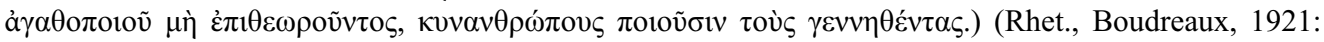
127)

Ancient and late ancient astrology attempted to predict the fate of a person based on the position of the planets at the moment of their birth (Barton, 1994; Beck, 2007). The position of the seven planets in the heavens and their geometric relationship to one another combined to produce a system with an array of variables resulting in a wide range of interpretative possibilities. The heavens were divided into 12 numbered segments, the so-called Topoi (= 'Places'), each of which permanently attributed a different meaning in the life of the newborn. The Twelfth Place, the section of the sky directly after the one in which heavenly bodies rose above the horizon, was considered without doubt to possess negative attributes: calamity, animosity and misfortune affecting all aspects of life were attributed to this region (Beck, 2007: 42-9). Sun and moon, the two luminaries, located in this calamitous Place each bring their own respective characteristics to the situation. Originally in ancient astrology, the planets were connected to the gods of the same name, with their respective characters reflecting those of the gods from Greek and Egyptian mythology (Barton, 1994: 111-13). Of the many characteristics attributed, mention should be made of the sun as 'leader and orchestrator' (Beck, 2007: 78) of the planets. In the field of medicine, the sun also stood for the head and for perception. The moon, which tended to be positively associated in astrology with growth and the development of life (Beck, 2007: 74), also contains the link to kynanthropy: the dog functioned as the sacred animal of the moon goddess Selene (and other nocturnal deities such as Hecate, the goddess of sorcery).

The calamitous meaning of the Twelfth Place is intensified in the situation in question by the fact that the inherently maleficent planets Saturn and Mars are strengthened through their position at so-called 'cardinal points'. The four cardinal points are the most important places: the Ascendant, where the sign rises above the eastern horizon; Midheaven; the Descendant, where it sets; and the Nadir or lowest point of the invisible sky (Places 1, 4, 7 and 10). Originally, the term 'horoscope' was simply the Greek for 'Ascendant' (Barton, 1994: 92-6). Another passage in Rhetorius's compendium mentions the same kynanthropy-generating situation in other words (Boudreaux, 1921: 183): here, the changeable and unstable Mercury serves as the third maleficent planet whose negative influence is amplified by a cardinal position. The two remaining planets, benevolent Venus and Jupiter, are not able to exert their counteraction due to their weak geometrical position in relation to Sun and Moon - 'not in the right aspect'.

To conclude, kynanthropy needs a very specific celestial configuration in order to occur inevitably in the person born at that moment. The question must remain open, however, as to what exactly the astrological texts are referring to when they use the term 'kynanthropy': does this refer to madness, as the term is used in the field of medicine, perhaps comparable with the madness of Amida? Or is this simply a case of dog-like behaviour in general? The Latin translation of 'kynanthropy' in the Hermes Trismegistos manuscript edited by Wilhelm Gundel, most probably from late antiquity, does not throw light on the question either (Gundel, 1936: 110). It simply reads 'canes homines', literally: dogs men. Perhaps the translator did not know what the term meant, or the Latin language had neither its own term nor a foreign word available.

One can say with certainty, however, that kynanthropy had extremely negative connotations in astrology. It not only requires an extraordinarily calamitous celestial configuration, but in some sources the same configuration is also said to be responsible for 'kynobrôtos' - 'devoured by dogs' (Antiochus, Boll, 1908: 115; Rhetorius, Boudreaux, 1921: 183). In this case, too, it is not entirely 
clear what is being referred to. Cumont (1937: 187) argues that it could be a term used to denote abandoned children eaten by wild dogs, an apparently widespread topos in astrology. Another reasonable suggestion is that the body is eaten by dogs after death, a behavioural pattern attributed to dogs across all ancient source types (Loth, 1994: 815; Metzger, 2011: 174-5). Both of these possibilities place kynanthropy in gruesome company.

The nature of the connection between the medical and astrological references to kynanthropy must also remain open. The earliest astrological mention can be traced back to Antiochus of Athens (Boll, 1908: 114-15), who was writing during the second century AD (Pingree, 1977: 203-5), i.e. roughly at the same time as Marcellus of Side, who introduced kynanthropy to the field of medicine. It can be safely assumed that the medical and astrological sources are not the only texts to have dealt with kynanthropy, but simply the only surviving texts, with other possible sources having been lost, since dog-like behaviour or dog madness were obviously significant enough for contemporaries to have invented and used a term especially to denote this phenomenon.

\section{The significance of canine behaviour}

What does it mean to behave like a dog? While today, faithfulness and friendship between humankind and the animal tend to be emphasized, the character of the dog in antiquity and late antiquity was much more negatively viewed. While there was recognition for hunting, house and herding dogs in their function as working animals (Loth, 1994: 803-5), their praiseworthy characteristics in this context, such as vigilance, faithfulness and great and often selfless commitment to the respective cause of their master refer specifically to the tasks, and are never portrayed as being inherent to the character of the animal. Stray dogs without a master or those not trained for specific tasks were viewed with particular scorn: such dogs were considered cowardly, brazen, greedy, excessive, sycophantic, cruel and unclean (Loth, 1994; Orth, 1913: 2567-9; Scholz, 1937).

Similar character traits are attributed in the physiognomic texts of late antiquity to people who display 'dog-like' physical characteristics, such as a pointed face and nose (acutus vultus, acuta naris), an elongated body (longum corpus) (Förster, 1893: 139) and so-called dog teeth (labia

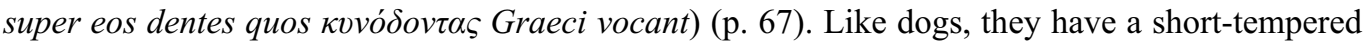
nature, like to flatter others, indulge in good food - the Greek source uses the term 'gluttonous' and are watchful and easily insulted (Canis animal est quod facile irascitur, facile blanditur, cibis

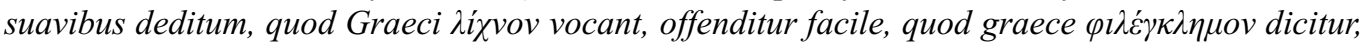
vigilat facile) (p. 139).

As mentioned above, dogs (along with wolves and birds) were thought to feed on dead bodies, reaping the benefits of war and disease, but also featuring prominently in Christian legends, in which the bodies of martyrs were thrown to the dogs rather than buried (Loth, 1994: 819-20). It was also said that they would not stop short of eating abandoned babies. The burial grounds beyond the gates of cities were typical places for dogs to be found. In Hellenistic religion and mythology, dogs are thus also depicted as animals accompanying and symbolizing deities of death, the underworld and sorcery, such as Hades (cf. Cerberus) and Hecate, who is sometimes portrayed with the head of a dog (Loth, 1994: 788-90; Roscher, 1896: 30-50; Scholz, 1937). In the pre-Christian folklore of the old Orient, the Jews, the Greeks and the Romans, demons often take on the form of dogs and are to be found in and around burial grounds (Böcher, 1970: 86-8; Loth, 1994; on Greek tradition only: Herter, 1950: 133; Johnston, 1999: 212).

While these fundamental characteristics and attributions of the dog remain very stable between classical and late antiquity, the Christian perspective transformed the principal concepts of distinction between humans and animals. While the transition between them seemed to be rather blurred in classical times - there are countless examples of in-between phenomena and unclear boundaries 
(Gilhus, 2006: 13-16, 37-63; Thumiger, 2008: 3-5; for Indian Dog-heads, see Campbell, 2006: 114-19) - the Christian belief in the redeemable, immortal soul, which animals do not possess, represented a categorical and absolute separation (Salisbury, 1994: 4-7). Philosophers and sophists of the early Imperial period were still intensively discussing the distinction between animals and humans and how one should deal with the former: Platonists tended towards animal ethics and vegetarianism, while Stoics declared animals to be devoid of rationality and saw them as serving the needs of humans (Gilhus, 2006: 37-63). In the Christian thought of late antiquity, the latter position gained the upper hand. Gilhus (2006) argues that particularly the desanctification of the slaughter of animals contributed to this, since meat was only eaten following sacred sacrifice in pre-Christian times, whereas Christians killed animals without any religious context, which led to a functionalization and a 'lowering of the status of animals' (Gilhus, 2006: 3). Animalistic behaviour was associated only with lowly cravings and the body.

The reputation of the dog thus sank further following the advent of Christianity (although it continued to be held in high esteem as a worker): the enemies of Christianity were denounced as 'dogs', while the dog also served as a common point of comparison for the sins of gluttony, greed and fornication. Dogs are often and repeatedly connected with demons, for example in hagiography, with demons either appearing in the form of dogs, possessing dogs, or possessed people behaving like dogs (Loth, 1994: 803-26). This is in keeping with the Jewish tradition (Böcher, 1970: 87-8; Loth, 1994: 782-6) and, by the seventh century at the latest, it was so firmly established that some monasteries refused to keep these 'unclean' animals (Loth, 1994: 805).

\section{Interpretations of canine madness}

Canine madness in the sources of late antiquity is thus neither limited to the Syriac-language religious literature (John of Ephesus) nor is it to be found only in the medical sources (Aëtius Amidenus). Astrological treatises mention kynanthropy as a keyword, the meaning of which must have been known to the reader. Along with the descriptions of dog-like behaviour of the possessed in Christian literature, it is plausible to assume that such behaviour represented an established expression of behaviour deviating from the norm. The earliest traces of kynanthropy or dog madness can be dated back to the second century AD in some pre-Christian societies (Marcellus of Side, Antiochus of Athens). We are therefore concerned with a widespread phenomenon from the Roman Imperial period onwards, which fits with the chronologically and geographically stable significance of the dog in Greek and Middle Eastern cultures.

The general cultural phenomenon 'dog madness' only appears at the fringes of research literature; existing studies focus either on the interpretation of the madness of Amida or on the medical concept of kynanthropy. The following section will present and evaluate several important cultural history interpretations from current research, firstly on the madness of Amida.

For the religious historian Susan Ashbrook Harvey (1990: 65), a 'sense of trauma' emanates from the intensive description of the madness of Amida by John of Ephesus which permeates the collective memory of the event. 'The account of Amida's plague of madness ... stands as testimony to the fact that society, like the individual, does have a breaking point.' The expression and extent of the madness are in keeping with the cultural background; numerous comparable examples of mass hysteria can be found in pre-modern times. Harvey's reference to the fundamental concept of psychotraumatology is immediately plausible to us as modern readers. She does not need to specify that in using the term 'trauma', she refers to a psychological reaction to a previous traumatic event, rather than an injury in the surgical sense of an accident, for example. Even outside the parameters of specialist discussions, the concept of psychological trauma is nowadays a firmly established part of the way non-experts perceive certain psychological processes. However, 150 years earlier, in the 
middle of the nineteenth century, this would not have been the case: at that time, the term psychological trauma was neither commonly known nor even existent in the fields of medicine and psychology, for the concept of 'injury to the psyche' did not become established until the beginning of the twentieth century (Metzger, 2014). Even an attempt to use the DSM-IV for the categorization of the madness of Amida, as the classicist Jerry Toner (2013: 464-5, 472) undertakes - although he immediately acknowledges the limited value of this for the historian - not only achieves nothing in the way of improved understanding, but also distorts the unique characteristics of the historical case of madness. Although the chronicler of the events, John of Ephesus, also sees a connection with past catastrophes, the outbreak of collective madness represents in his view the climax of a series of divine tests. The madness does not come from within the afflicted person ('psyche'), but rather from an external source as if it were a plague of some sort.

Toner (2013) accuses John of Ephesus of portraying a 'Christian dystopia' for the benefit of his own agenda in his depictions of both the plague and the madness of Amida. He tells 'shocking stories to advertise the perfect Christian society' (p. 472). Altogether, he claims, the disasters of late antiquity encouraged Christianization, as they demonstrated that 'each individual was held in the comforting embrace of the Church' (p. 470). Unfortunately, Toner is unable to support this bold claim, either with convincing arguments or with evidence, as is also the case with most of his other thoughts.

The comprehensive work by Meier (2003) on catastrophes and the experience of contingency presents an entirely different perspective. He interprets the madness of Amida (pp. 424-6) along with the madness in times of plague (pp. 378-82) as an expression of the failure of established coping strategies: confidence is lost first in the Emperor and the authorities once they are no longer in a position to react to calls for help and fulfil their obligations as protectors due to the number and extent of the disastrous events. Hope is then increasingly placed in religious interpretation and protection strategies: the worship of icons and saintly cults springs up or becomes more intensive. But religion, too, fails in the face of the horror brought about by the great plague, for example, for how can it provide such events with any sense of purpose? Rage is then directed at monks and ecclesiastical authorities who are not in a position to protect the population from disaster or explain its indiscriminate destruction. For Meier (2003: 423), the mass onset of madness in Amida embodies the failure of 'religious and state protection mechanisms', since the 'insane' acted specifically against the 'Christian norms and state force'. They gave expression in their 'mad' behaviour to their disillusionment. Madness remained the last option for those afflicted to react to the incomprehensible, which, from today's perspective, is actually a fairly rational answer (Meier, 2003: 377).

The medievalist Gregor Rohmann (2013: 323-9), on the other hand, criticizes Meier's interpretation in his cultural history work on the pre-modern phenomenon of mass hysteria, and feels it is too caught up in the concepts of modern psychology. His own interpretation is situated closer to that of the participants themselves: those afflicted by the madness find themselves in a state of 'loss of salvation', feeling deserted by God due to the numerous catastrophes and thus losing their faith. They give physical expression to this state of mind through their madness, showing a 'performance of removal from salvation'. The content of the madness is dependent on culture: those afflicted base their expression on existing patterns for the behaviour of possessed persons, as those who were far removed from God's salvation were considered easy prey for demons. 'They saw themselves as being possessed by demons and behaved as such.' (p. 326).

A causal connection between dog-like behaviour and rabies as observed in dogs was often established, not only for the medical condition of kynanthropy (Kroll, 1940), but also frequently for possession (Böcher, 1970: 86-7). This explanation, rather elegant at first glance, nevertheless overlooks not only the fact that ancient medicine was familiar with rabies as an illness in its own right which was transmitted through a bite from a rabid dog (Celsus 5,27,2, Marx, 1915: 230), but 
also that the affliction was known outside specialist medical circles, as magical formulas for its cure, for example, demonstrate. Contemporaries were thus clearly in a position to distinguish between a rabid and a mad patient; and hence also between the behaviour of a healthy and a rabid dog (Théodoridès, 1984). While rabies was admittedly often interpreted as possession in both humans and animals, not all those who were supposedly possessed displayed symptoms of rabies. The behaviour of a 'normal' dog was enough for a diagnosis of madness or possession.

One of the few cultural history interpretations of the medical concept kynanthropy is provided by Wilhelm Roscher (1896). Since kynanthropy is coupled with lycanthropy, i.e. wolfish madness, in the work of Aëtius, Roscher bases his study, which is still of fundamental significance today, on the question of what dog and wolf actually have in common in the conceptual world of (pagan) antiquity. The answer is: not very much - except that both animals functioned as agents of the underworld, accompanying animals of Hecate, the goddess of sorcery, and of a variety of deathrelated deities. He argues that the symptoms were considered to symbolize the fact that sufferers were being transported to the underworld while still alive, which would also explain their nocturnal visits to burial grounds.

Even though this interpretation is fairly extreme, it is nevertheless to be noted that both dog and wolf were associated with negative characteristics in the ancient world, albeit of differing natures. While wolves were considered symbols of wildness and lawlessness as an opposing pole to human civilization (Metzger, 2011), dogs were left to fill out the 'depths of society': servile, cowardly, filthy, feeding on carcasses. Perhaps the difference between the perception of wolf and dog is also the reason why authors such as Oribasius chose to omit the kynanthropy of their sources, including only lycanthropy in their works (Orib. Syn. VIII 9, Raeder, 1926: 250). Aëtius, on the other hand, could have deliberately retained the dog, since he attributed significance to canine madness due to his Christian background. In this way, he is able to explain the well-known sign of demonic possession in terms of natural science as a melancholic illness using the principles of ancient medicine. However, there is no direct evidence to support such speculation, and the reduction of the medical concept of kynanthropy to an attempt at rationalization is, furthermore, an historically unsatisfying solution (Metzger, 2011: 139-41). Such a solution cannot explain why canine madness in particular appeared as a widespread cultural phenomenon.

Demonology and medicine are not easy to separate in the case of John of Ephesus either. Alongside his demonological categorization, he repeatedly uses neutral terms to describe the events, similar to those used for illnesses (at least in the translation by Witakowski, 1996: 104-6). He seems to refrain in these passages from making an explicit judgement, largely allowing the symptoms to speak for themselves. In the world view of his time, an interpretation of events as illness or as possession are not necessarily mutually exclusive (Dols, 1984: 144-5; Rohmann, 2013: 327-8), since illness can be of demonic origin, while certain physical conditions can also make it easier for demons to enter the body.

The measures taken by the few remaining healthy members of the population to assist their fellow citizens also contain medical elements. John describes how the unscathed Amidans attempted to gather those suffering from the madness into churches and to keep them under control. This was in accordance with common practice when dealing with the mentally ill in late antiquity (Dols, 1984: 145-6). They treated the captives in the church with a special diet which also contained fatty foods and wine. Once the sexual excesses of the madness sufferers (in the churches!) became known, attempts were made to curtail these with dry and bitter foods (Zuqnin Chronicle, Witakowski, 1996: 105-6). The spiritual care through proximity to holiness was thus combined with the basic medical method of diet manipulation.

The extent to which John was familiar with specialist medical literature beyond the basic medical education, and indeed whether he knew of the medical condition kynanthropy, must remain open. 
Any assumption of a personal acquaintance or even knowledge exchange between John and Aëtius would be purely speculative. Even if they had indeed been contemporaries, which is by no means certain, the paths of their lives and their fields of operation lead in different directions. John's work focuses on the interests of the Monophysite minority in Mesopotamia, while Aëtius left Amida early on, in order to obtain an education and later pursue his professional career. Although it is fairly certain that John was able to speak Greek - he was familiar with Greek-language church history (van Ginkel, 1995: 94-6) - and he lived in Constantinople, there is no proof that he read Aëtius's medical compendium or that he was familiar with the medical concept of kynanthropy. It is obvious that John does not describe kynanthropy, but rather simply names symptoms in common with it, among a wide variety of symptoms evident during the madness of Amida.

\section{The cultural significance of canine madness}

A general interpretation of all phenomena of dog madness in late antiquity must look beyond the genre of the texts and ask the fundamental question as to the cultural significance attributed to abnormal, dog-like behaviour during the period under investigation, regardless of whether it was considered to be a case of illness or demonic possession.

The great variety found in the behavioural patterns of the Amidans as compiled by John of Ephesus leaves no doubt as to the fact that this was a presentation of a tableau of demonic possession. The loss of all self-control, shame and conscience - indiscriminate sexual activity in public, blasphemy, loud, uncontrolled noises - particularly on a collective scale, is abnormal behaviour which Christians of late antiquity would best have been able to explain as being due to demonic influence. Many of the very specific symptoms, such as dog-like behaviour, the exclamation of senseless words and curses, the imitation of trumpets, frothing at the mouth and blasphemous speeches, are also typical signs from this period of a demonic possession (Rohmann, 2013: 326-7). In the course of such a possession, sufferers fall out from the community and from the Christian closeness to God and, following the abatement of the madness, they must find their way back through pilgrimages and penitence (John of Ephesus, Witakowski, 1996: 106-7).

The dog-like behaviour, including movement on all fours and (dog) bites, which is mentioned by both John of Ephesus and Aëtius Amidenus, are able to symbolize this fall from the community; the sufferers thus proceed to leave behind human civilization, respect and self-respect, crossing the border into the realm of animals and subsist there in a lower form of existence.

The fact that those afflicted by the madness in Amida and sufferers of the medical condition kynanthropy spent large amounts of time in burial grounds, particularly at night, highlights the separation of the patients from the 'normal' human community. In the sixth century, burial grounds were not yet sacred locations with 'consecrated earth' (Rohmann, 2013: 328-9), instead lying outside the city walls, and had been perceived since antiquity as being generally dangerous places: the refuge of the lawless and of demons. No Amidan in their right mind would spend time there at night. Graveyards in Christian sources are also typical places inhabited by the possessed, as shown, for example, by the demon expulsion of Gerasa from the New Testament (Matthew 8: 28-34; Mark 5: 1-20; Luke 8: 26-39) (a reverse interpretation of the demon-possessed man of Gerasa as a kynanthrope, as Stocks (1907) suggests, draws illegitimate conclusions on the individual case based on the general evidence). The time spent in burial grounds is a spatial demonstration of the mental separation of the mad or possessed from the city's sphere of civilization (Metzger, 2011: 253-4).

All the symptoms that the madness of Amida and Aëtius's kynanthropy have in common can be placed within a space of cultural meaning. For what is madness other than abnormal behaviour in terms of the contemporary normative line of separation between normal and mentally ill or possessed? Sufferers of the madness of Amida rejected fundamental aspects of human civilization, 
demonstrating through their behaviour that they do not belong in the well-ordered space of regulated communal living, but rather in the self-abandonment of an animal, devoid of reflection and shame.

But why is the dog in particular the symbolic animal which is utilized in both the medical and the religious contexts? John of Ephesus names dog-like behaviour as the first symptom, before all other animal-like behaviour and all other behavioural patterns. In the narrative of the madness of Amida, 'canine behaviour sets the stage'. The reader can immediately tell the direction in which John's description is moving: yielding to any form of physical lust, sins of the lowest kind, possession and the loss of the privileged relationship of humankind to God. The dog thereby stands for the most animalistic of all animals: it is irrational, shameless, uncontrolled, follows all its lowest instincts and, as it feeds on dead bodies, occupies the lowest level of feeding behaviour. It is contemptible in terms of both character and behaviour; while the wolf functions as an opposite pole to human civilization (Metzger, 2011), the dog represents the lowest regions of human existence itself, the reduction of the human to the animal element. Controlling or even overcoming precisely this animalistic side of human nature, represented by the body and its urges, is the civilized aim of both the Christian and Neoplatonic conduct of life in late antiquity. Human beings align themselves with God, everything else being considered madness from this perspective - a madness which can best be symbolized by the dog, the most animalistic of all the creatures.

\section{References}

(a) Primary sources

Boudreaux P (ed.) (1921) Catalogus Codicum Astrologorum Graecorum (VIII,4). Codicum Parisinorum. Partem quartem. Bruxelles: Mauritius Lamertin. [Rhetorius]

Boll F (ed.) (1908) Catalogus Codicum Astrologorum Graecorum (VII). Codices Germanicos. Bruxelles: Henricus Lamertin. [Antiochus]

Förster R (ed.) (1893) Scriptores physiognomonici Graeci et Latini, Vol. 2. Leipzig: Teubner.

Gundel W (1936) Neue astrologische Texte des Hermes Trismegistos. Funde und Forschungen auf dem Gebiete der antiken Astronomie und Astrologie. München: C.H. Beck (Abhandlungen der Bayerischen Akademie der Wissenschaften, Philosophisch-Historische Abteilung, N.F., vol. 12).

Kühn CG (ed.) (1830) Claudii Galeni Opera omnia, Vol. 29. Leipzig: Cnobloch.

Marx E (ed.) (1915) A. Cornelii Celsi quae supersunt. Leipzig, Berlin: Teubner (Corpus Medicorum Latinorum, vol. 1).

Olivieri A (ed.) (1950) Aetii Amideni libri medicinales 5-8. Berlin: Akademie-Verlag (Corpus Medicorum Graecorum, vol. 8,2).

Raeder J (ed.) (1926) Oribasii Synopsis ad Eustathium. Libri ad Eunapium. Leipzig, Berlin: Teubner (Corpus Medicorum Graecorum, vol. 6,3).

Trombley FR and Watt JW (transl.) (2011) The Chronicle of Pseudo-Joshua the Stylite. Liverpool: Liverpool University Press.

Witakowski W (transl.) (1996) Pseudo-Dionysius of Tel-Mahre: Chronicle. Part III. Liverpool: Liverpool University Press. [Chronicle of Zuqnin]

\section{(b) Secondary sources}

Barton T (1994) Ancient Astrology. London, New York: Routledge.

Beck R (2007) A Brief History of Ancient Astrology. Oxford: Blackwell.

Böcher O (1970) Dämonenfurcht und Dämonenabwehr. Ein Beitrag zur Vorgeschichte der christlichen Taufe. Stuttgart: Kohlhammer.

Campbell GL (2006) Strange Creatures. Anthropology in Antiquity. London: Duckworth.

Cumont F (1937) L'Egypte des Astrologues. Bruxelles: Fondation Egyptolog. Reine Elisabeth.

Dignas B and Winter E (2007) Rome and Persia in Late Antiquity. Neighbours and Rivals. Cambridge: Cambridge University Press. 
Dols M (1984) Insanity in Byzantine and Islamic Medicine. In: Scarborough J (ed.) Symposium on Byzantine Medicine. Washington: Dumbarton Oaks Research Libr. and Collection, 135-148.

Gilhus IS (2006) Animals, Gods und Humans. Changing Attitudes to Animals in Greek, Roman and Early Christian Ideas. New York, London: Routledge.

Greatrex G (1998) Rome and Persia at War, 502-532. Leeds: Francis Cairns.

Harvey SA (1990) Asceticism and Society in Crisis. John of Ephesus and the Lives of the Eastern Saints. Berkeley, CA: University of California Press.

Herter H (1950) Böse Dämonen im frühgriechischen Volksglauben. Rheinisches Jahrbuch für Volkskunde 1: $112-143$.

Ieraci Bio AM (2010) Aezio di Amida. In: Radici Colace P et al. (eds) Dizionario delle Scienze e delle Tecniche di Grecia e Roma. Pisa: Serra, 38.

Johnston SI (1999) Restless Dead. Encounters Between the Living and the Dead in Ancient Greece, Berkeley, CA: University of California Press.

Kroll W (1940) Kynanthropie. In: Realencyclopädie der classischen Altertumswissenschaft, Suppl. 7. Stuttgart: Metzler, 337-338.

Loth H-J (1994) Hund. In: Reallexikon für Antike und Christentum, Vol. 16. Stuttgart: Hiersemann, 773-828.

Martindale JR (1980) Aetius (of Amida). In: The Prosopography of the Later Roman Empire, Vol. 2. Cambridge: Cambridge University Press, 20.

Meier M (2003) Das andere Zeitalter Justinians. Kontingenzerfahrung und Kontingenzbewältigung im 6. Jahrhundert n.Chr. Göttingen: Vandenhoeck \& Ruprecht.

Metzger N (2011) Wolfsmenschen und nächtliche Heimsuchungen. Zur kulturhistorischen Verortung vormoderner Konzepte von Lykanthropie und Ephialtes. Remscheid: Gardez Verlag.

Metzger N (2013) Battling demons with medical authority: werewolves, physicians and rationalization. History of Psychiatry 24(3): 341-355.

Metzger N (2014) Railway spine, shell shock and psychological trauma. The limits of retrospective diagnosis. In: Becker EM, Dochhorn J and Holt EK (eds) Trauma and Traumatization in Individual and Collective Dimensions. Insights from Biblical Studies and Beyond. Göttingen: Vandenhoeck \& Ruprecht, 43-61.

Nollé J (1993) Side im Altertum. Geschichte und Zeugnisse, Vol. 1. Bonn: Habelt.

Orth F (1913) Hund. In: Realencyclopädie der classischen Altertumswissenschaft, Vol. 8,2. Stuttgart: Metzler, $2540-2582$.

Pingree D (1977) Antiochus and Rhetorius. Classical Philology 72: 203-223.

Rohmann G (2013) Tanzwut. Kosmos, Kirche und Mensch in der Bedeutungsgeschichte eines mittelalterlichen Krankheitskonzepts. Göttingen: Vandenhoeck \& Ruprecht.

Roscher WH (1896) Von der "Kynanthropie" handelnde Fragmente des Marcellus von Side. Leipzig: Hirzel (Abhandlungen der philosophisch-historischen Classe der Königl. Sächsischen Gesellschaft der Wissenschaften, Vol. 20).

Salisbury JE (1994) The Beast Within. Animals in the Middle Ages. New York, London: Routledge.

Scholz H (1937) Der Hund in der griechisch-römischen Magie und Religion. PhD thesis, Friedrich-WilhelmsUniversität Berlin.

Segal JB (1955) Mesopotamian communities from Julian to the rise of Islam. Proceedings of the British Academy 41: 109-139.

Stocks H (1907) Ein Fall von Kynanthropie im Neuen Testament: Matth. 8, 28 ff. und Parallelen. Neue kirchliche Zeitschrift 18: 499-506.

Théodoridès J (1984) Rabies in Byzantine medicine. In: Scarborough J (ed.) Symposium on Byzantine Medicine. Washington: Dumbarton Oaks Research Libr. and Collection (Dumbarton Oaks Papers, vol. 38), 149-158.

Thumiger C (2008) ảvó $\gamma \kappa \eta \varsigma \zeta \varepsilon v ́ \gamma \mu \alpha \tau ’ \dot{\varepsilon} \mu \pi \varepsilon \pi \tau \omega ́ \kappa \alpha \mu \varepsilon v$. Greek tragedy between human and animal. Leeds International Classical Studies 7(3): 1-21.

Toner J (2013) The psychological impact of disasters in the age of Justinian. In: Harris WV (ed.) Mental Disorders in the Classical World. Leiden: Brill, 461-473.

van Ginkel JJ (1995) John of Ephesus. A Monophysite Historian in Sixth-Century Byzantium. PhD thesis, Rijksuniversiteit Groningen.

Wellmann M (1893) Aetios (8) von Amida. In: Realencyclopädie der classischen Altertumswissenschaft, Vol. 1,1. Stuttgart: Metzler, 703-704. 